\title{
Stigma and dilemma: An ethnographic review on the medical personnel of the COVID-19 referenced hospital
}

\author{
D.W. Apriadi*, D. Mawarni \& M. Saputra \\ Universitas Negeri Malang, Malang, Indonesia
}

\begin{abstract}
The high number of COVID-19 cases in Indonesia has caused anxiety among the Indonesian people and has created a negative stigma attached to medical personnel because they are considered vulnerable to being exposed to COVID-19. The purposes of this research were (1) to find out the negative stigma attached to medical personnel, both from the family and society in the midst of the COVID-19 pandemic, (2) to explore the impact of negative stigma in the midst of the COVID-19 pandemic, and (3) to investigate the solutions applied to prevent and overcome the negative stigma amid the COVID-19 pandemic. This research employed a qualitative research approach, and the data was gathered using in-depth interviews via video calls and/or by telephone. The results of this study indicate that the negative stigma received by medical personnel comes from family, friends, neighbors, and even immediate family members. The attitudes shown are also of various kinds, such as discrimination, exclusion, bullying, and even expulsion.
\end{abstract}

Keywords: Stigma, Medical Personnel, COVID-19 Pandemic

\section{INTRODUCTION}

The beginning of the emergence of the first COVID-19 case in the City of Surabaya was March 17, 2020. The Ministry of Health of the Republic of Indonesia then issued a decree on the determination of Large-Scale Social Restrictions (PSBB) number HK.01. 07/MENKES/264/2020 on April 21, 2020. The East Java Provincial Government issued a Governor of East Java Decree number 188/202/KPTS/013/2020, stipulating the Enforcement of Large-Scale Social Restrictions (PSBB) in handling Covid-19 in the region. Surabaya City, Sidoarjo Regency, and Gresik Regency, for 14 days, from 28 April 2020 to 11 May 2020, issued the Governor of East Java Decree number 188/219/KPTS/013/2020 concerning the extension of PSBB's jurisdiction in handling COVID-19 in the City of Surabaya, Sidoarjo Regency, and Gresik Regency for 14 days starting from May 12, 2020, to May 25, 2020.

After the end of the PSBB, the mayor of Surabaya issued a regulation of the mayor of Surabaya number 28 of 2020 concerning Guidelines for the New Normal Order in the Conditions of the COVID-19 Pandemic in the City of Surabaya on June 10, 2020 as a guideline for implementing the new normal order in the conditions of the COVID-19 pandemic which includes changes in the culture of life communities which would be more productive in the COVID-19 pandemic situation by implementing a Clean and Healthy Lifestyle (PHBS) and health protocols which were expected to reduce the risk and impact of COVID-19. The increase in the number of COVID-19 patients raised anxiety in the community, which also raised various negative stigmas, especially for medical personnel who work in hospitals and are vulnerable to being exposed to COVID-19. In the United States study, nearly half were found to be feeling restless, according to a survey from the American Psychiatric Association (Varshney 2020). The psychological impact experienced by health workers is in the forms of stress and anxiety due to the social stigma that exists in society.

\footnotetext{
*Corresponding author: deny.apriyadi.fis@um.ac.id
} 
The stigmatization of health workers adds to the physical and mental fatigue that health workers bear during their working hours. Doctors or paramedics trying to save lives during these difficult times are refused habitation in their apartments. This is a difficult situation for medical personnel during the COVID-19 pandemic (Pradhan 2020). The stigma against medical personnel still occurs, but a movement to care for humanitarian fighters continues to emerge. Personal protective equipment (PPE) and aerosol boxes were donated by several communities to a number of hospitals in Indonesia. It is not only the task of the government but also the role of society to fight against COVID 19.

Stigma is a term that describes a situation or condition related to the point of view of something that is considered negative (Arboleda-Florez 2002). Stigma is understood as a social construction in which a distinguishing sign of social disgrace is attached to other people to identify and evaluate them. Stigma is common in the burden of disease (Wilsher 2011). Social stigma in the context of health is a negative relationship between a person or group of people who share certain characteristics and certain diseases (WHO 2020). Stigma can encourage people to hide illness to avoid discrimination, prevent people from seeking immediate health care, and prevent them from adopting healthy behaviors. The emergence of a negative stigma against medical personnel working in hospitals originated from the assumption that medical personnel who work in hospitals can transmit COVID-19 to people in the surrounding environment. Stigma hurts the person/group and has even more negative impacts on mental health compared to COVID-19 itself. The stigma that circulates in society can lead to discrimination, exclusion, and expulsion. Courtwright and Turner (in Craig et al. 2016) suggest that stigmatization is different from discrimination, as the former occurs with shame, while the latter involves exclusion. Stigmatization is seen as a complex process involving institutions, communities, and interpersonal attitudes. The purpose of this research is to find out the negative stigma attached to medical personnel, both from the family and society in the midst of the COVID-19 pandemic, to know the impact of negative stigma in the midst of the COVID-19 pandemic, and to know the solutions applied to prevent and overcome the negative stigma amid the COVID-19 pandemic.

\section{METHODS}

This research employed a qualitative research approach. Qualitative research is enacted based on the philosophy of interpretivism that is used to examine the condition of natural objects, where the researcher is a key instrument and the research results emphasize meaning rather than generalization (Sugiyono 2009). In qualitative research, what is used as the target of the study is the conditions of social life or society as a whole and comprehensive unit. This is related to the issues raised, namely regarding the socio-cultural problems of the community in the midst of the COVID-19 pandemic.

The data collection techniques used in this study were participatory observation, free, and indepth interviews via video call and/or telephone and were supported by a literature review. The process of selecting informants was taken purposively, in which the selected informants were those who understood the research problem raised, so that the data was appropriate and did not deviate far from the research topic. This study involved 30 informants from 15 referral and non-referral hospitals for COVID-19 in the City of Surabaya. The data analysis in this study was carried out through three stages, namely making field notes, reducing data, and drawing conclusions. Through this abstraction, the prevailing social institutions in the area or community where the research is conducted were seen (Ahimsa-Putra 2009). Findings in the field were processed with data obtained from the literature and were presented in a descriptive ethnographic work (Denzin \& Lincoln 2009).

\section{RESULTS AND DISCUSSION}

Pandemic checks and social stigma, as well as the strengthening and decentralization of COVID-19 medical facilities including testing, tracing, formal quarantining, and special care for COVID-19 
Table 1. Informant's data

\begin{tabular}{lc}
\hline Profession & Number \\
\hline Nutritionists & 1 \\
pharmacist assistant & 1 \\
Midwife & 8 \\
Medical Physics & 1 \\
Environmental Health & 1 \\
Nurse & 17 \\
Radiographer & 1 \\
\hline
\end{tabular}

patients must be ensured by a relatively large state budget and collaboration with the private sector for health management. The government of Bangladesh and some voluntary organizations should establish a Central Stigma Management Committee (CSMC) that would work with local committees that use relevant experts in the field and use official guidelines that can motivate people to support their families, communities/local residents, and their neighbors as a form of moral responsibility (Mahmud 2020).

Stigma is a strong social process characterized by labeling, stereotyping, and segregation that leads to loss of status and discrimination, all occurring in the context of power. Stigma also has an impact on the welfare of health workers because health workers live in a stigmatized condition (Nyblade 2019). The social stigma that appears in the community regarding medical personnel is the result of a lack of knowledge of COVID-19 (transmission of the disease, ways of handling, and prevention). The risk of transmission should be given by the local community or local officials to the community to avoid rumors or misinformation circulating so that the information circulating is correct information based on scientific evidence. Health workers at the forefront of handling COVID-19 cases have a high level of risk of being exposed to COVID-19. There are a lot of negative stigmas that Indonesian health workers receive from areas affected by the pandemic. Nurses often face a negative stigma since people think they may spread the virus. Health workers who are at the forefront of handling COVID-19 cases have a high level of risk of being exposed to COVID-19.

Apart from Indonesia, this also happens abroad; as newspaper reports in mid-March 2020, a female doctor working at Dhaka Medical College received an ultimatum from the owner of her neighboring apartment in Old Dhaka to leave her apartment or job, otherwise, they threatened to expel her from the building (Kamal 2020 in Mahmud 2020). The massive effects of the social stigma associated with COVID-19 are so concerning that previous social norms, social values, and relationships, as well as social capital, have been shattered in surprising ways.

This study involved medical personnel who worked in 15 hospitals in the city of Surabaya. The proportion of informants who participated in this study can be seen in the diagram below. The number of informants who participated in this study was 30 people. The 30 informants have jobs as nutritionists, assistant pharmacists, midwives, medical physics, environmental health, nurses, and radiographers. Medical personnel who live in Surabaya receive more of the negative stigma from their environment. This is due to the high number of COVID-19 patients in Surabaya, which is the highest in East Java.

Based on the results of interviews, some of the medical personnel experienced negative stigma. The negative stigma received by medical personnel comes from neighbors and even immediate family members. The attitudes shown are also of various kinds, such as discrimination, exclusion, and bullying, the worst of which is expulsion. The negative stigma in the form of bad treatment also came from neighbors, and this was experienced by DS (29). DS received unpleasant treatment because she was in charge of handling Covid-19 patients. This had an impact on her mother's shop, which no one visited. DS herself felt that it was okay to be excommunicated. DS's children are ostracized by their neighbors and friends, namely their neighbors and their friends' parents do not allow their children to play with DS's children. DS feels grateful because her son does not have 
an emotional attitude. That is, he accepts the treatment and prefers to stay at home and play with his younger siblings. DS and her family have never experienced evictions from their neighbors at home. DS's father was worried because he worked dealing with COVID-19 patients, but DS tried to explain, and finally, her father understood and accepted DS's explanation. DS explained to her father that she had to go home to take care of her family, and as long as she could maintain cleanliness and health, nothing would happen.

The neighbors around the house and those who live in the boarding houses experience a more unpleasant incident, as experienced by MM (30). MM was excommunicated by his boarding house neighbor for about one month. His neighbors were indifferent and did not communicate with MM, even the owner of the boarding house also isolated him. Before the pandemic, he chatted with his neighbors, while during the pandemic there was no opportunity to chat with his neighbors. MM performs a SWAB test at the hospital, which is renewed every three months. The SWAB test results showed that he was negative, indicating that he was not exposed to COVID-19. MM's boarding house neighbor who knew about it experienced a change in attitude from initially ignoring and isolating from $\mathrm{MM}$ to returning to normal.

The stigma that comes from the nuclear family is experienced by YC (32). The response of the family and the environment related to work as medical personnel working at the COVID-19 referral hospital is that food should not be shared, YC's cutlery or utensils are kept away from other family members to reduce direct contact. YC often drinks bottles of mineral water by not using the glass so that the glass he has used is not used by other family members.

YS (30) received a negative stigma from the community because her husband was suspected of being positive for COVID-19 and because, according to him, most people were ordinary people who did not understand health, so many viewed their family negatively. YS has also reduced direct contact with neighbors since the pandemic. The bad experience because of the negative stigma of society was obtained by YS when she wanted to buy antiseptic from her neighbor after the neighbor knew YS's name and address, the neighbor looked worried, then YS decided to buy somewhere else and didn't think too much about it. Some neighbors stay away from their families, but there are also those who still want to be in touch with them; for example, a neighbor wants to deliver an order that YS bought from the neighbor to his house. Negative stigma can even come from the workplace and from fellow health workers. The negative stigma of the work environment is experienced by DN (26). DN had the experience when he first guarded the COVID-19 room. None of his friends wanted to talk to him for fear of catching the virus, including the doctor who was on duty at the ER. DN experienced discrimination in the hospital after guarding the COVID-19 room. The impact of negative stigma from the environment and society causes anxiety and disrupts a medical professional's psychological condition. The impact of this negative stigma makes medical personnel reluctant to socialize with their neighbors and extended family, as was done by DN.

Facing this negative stigma, the hospital provides several policies, such as the rapid test, which is carried out regularly and even the SWAB test for medical personnel who need it, the use of PPE for medical personnel, as well as a place to stay in the hospital for medical personnel who want to stay in the hospital. Rapid tests are carried out periodically at the seven hospitals where the informant comes from. If the results are positive, then a SWAB test will be followed. There are seven hospitals that provide rooms, such as hotels or pavilions, that are used for medical personnel who do not want to return to their homes.

ST (27) often takes the rapid test in the hospital, and he is quite safe because he does not show symptoms such as cough, fever, and other symptoms. The symptoms experienced by COVID-19 patients are not very specific because many people are without symptoms. If the rapid test shows positive results, it is necessary to take a SWAB test. The workplace provides its own rapid test facilities to encourage testing and avoid transmission to worker's families. The most important test is rapid. If the results are negative, then the worker is safe and rest and vitamins are recommended. If the result shows a positive result, then a SWAB should be done. If the worker shows a positive rapid result, then they are not allowed to go home and must be isolated in the hospital. 


\section{CONCLUSION}

Several medical personnel experienced a negative stigma during the COVID-19 pandemic. Medical personnel faced negative stigma from family, friends, neighbors, and even their immediate family members. The attitudes shown were also of various kinds, such as discrimination, exclusion, bullying, and expulsion from their residence. The impact of negative stigma from the environment and society causes concern and disrupts medical personnel's psychological condition. The impact of this negative stigma makes medical personnel reluctant to socialize with their neighbors and their extended families. Facing this negative stigma, the hospital provides several policies such as rapid and/or SWAB tests that are carried out regularly with medical personnel, especially for COVID-19 teams.

\section{REFERENCES}

Ahimsa-Putra, H.S. 2009. "Paradigma Ilmu Sosial-Budaya : Sebuah Pandangan.” Seminar paper, Universitas Pendidikan Indonesia, Bandung, 7 Desember 2009.

Arboleda-Florez, J., 2002. "What causes stigma?", World Psychiatry, 1(1), hlm.25-26. https://www.ncbi.nlm.ni h.gov/pmc/articles/PMC1489829/.

Craig G. M, A. Daftary, N. Engel, S. O’Driscoll, and A. Ionnaki. 2016. Tuberculosis Stigma as a Social Determinant of Health: A Systematic Mapping Review of Research in Low Incidence Countries. Denmark: Science Direct.

Denzin, N.K. dan Lincoln, Y.S. 2009. Manajemen Data dan Metode Analisis. Handbook Of Qualitative Research. Yogyakarta: Pustaka Pelajar.

Mahmud, Ashek and M. Rezaul Islam. 2020. Social Stigma as a Barrier to COVID-19 Responses to Community Well-Being in Bangladesh. Switzerland: Springer Link.

Nyblade Laura, Melissa A. Stockton, Kayla Giger, Virginia Bond, Maria L.Ekstrand, Roger Mc Lean, Ellen M. H. Mitchell, La Ron E. Nelson, Jaime C. Sapag, Taweesap Siraprapasiri, Janet Turan, and Edwin Wouters. 2019. Stigma in Health Facilities: Why It Matters and How We Can Change It. Washington DC: BM Medicine.

Pradhan Ravi Ranjan and Richa Nepal. 2020. Stigmatization Towards Healthcare Worker During the COVID-19 Pandemic in Nepal. Nepal: Nepalese Medical Journal.

Sugiyono. 2009. Metode Penelitian Kuantitatif, Kualitatif, dan R\&D. Bandung: Alfabeta.

Varshney Mohit, Jithin Thomas Parel, Neeraj Raizada, and Shiv Kumar Sarin. 2020. Initial Psychological impact of COVID-19 and its correlates in Indian Community: An Online (FEEL COVID) Survey. New Delhi: Plos One.

Wilsher, E. J. 2011. The impact of Neglected Tropical Diseases, and their associated stigma, on people's basic capabilities. Durham University. 